Volume 6 Issue 4, December 2019

Nationally Accredited Journal,

Decree No. B/4130/E5/E5.2.1/2019

\title{
The Implementation of Complete Systematic Land Registration (PTSL) Which the Transfer of Rights of His Land Not Using PPAT Deed (Case Study in National Land Agency of Grobogan)
}

\begin{abstract}
Reni Widayanti ${ }^{1}$, Jeifson Sitorus ${ }^{2}$ and Gunarto ${ }^{3}$
Abstract. Registration of land as a form of implementation of the government's obligation to guarantee legal certainty and the protection of land ownership. The purpose of this research are: 1) To analyze the Complete implementation of Systematic Land Registration in Grobogan. 2) To analyze barriers that occur in the Implementation of Complete Systematic Land Registration in Grobogan. 3) Analyze solutions to the obstacles to the full implementation of Systematic Land Registration in Grobogan. This study using sociological juridical approach namely a study conducted in depth against the reality-a reality that exist within the community and surrounding environment for the purpose of finding facts there and then will discuss the problems that exist.

Based on the results of data analysis concluded that that There are several stages in the implementation of location determination PTSL among other things, education, the establishment of the adjudication committee, the announcement of physical data and juridical. In the implementation of PTSL there are several barriers among others are plots of land still in dispute, plots the subject is still not clear, less pro-active society and other but officials PTSL seeks to overcome these obstacles with solutions that are effective in order stand on PTSL program is going well and smoothly in the interests of the general public.

Keywords: Complete Systematic Land Registration; Without PPAT Deed.
\end{abstract}

\section{Introduction}

Soil is a natural resource that is essential for human survival, and is one of the main elements in human life and is one of the natural resources which have an important function for economic development of Indonesian society. Land is required among other things to stay as well as to the business activities that are more varied in accordance with the development of economic, social, cultural and technological. In addition, the soil is one part of the basic needs of human life. Humans live and breed, as well as activities on the land, so that every moment of human contact with the land. The public need to be land from day to day continues to increase, in line with the pace of development in all areas carried out by the Indonesian nation. Thus the function of the land is progressing tailored to the needs of diverse nature.

Act of 1945, confirmed that Indonesia is a country based on law (rechstaat) and not based on power alone (machstaat). Similarly, about the land, the government is

\footnotetext{
${ }^{1}$ Student of Master of Notary Law, Faculty of Law, Sultan Agung Islamic University, Unissula, Semarang, email: widayanti.reni@ymail.com

${ }^{2}$ Student of Master of Notary Law, Faculty of Law, Sultan Agung Islamic University email jeifson_sitorus@yahoo.co.id

${ }^{3}$ Lecturer of Faculty of Law Unissula
} 
obliged to provide legal certainty on the status of land controlled by the people or entities and ensure the rights of all people. ${ }^{4}$

The purpose of government held land registration and issuance of certificates is one manifestation of the intended purpose of land registration. Act No. 5 of 1960 on Basic Regulation of Agrarian (BAL), through Article 19 mandates that the government held land registration for the entire territory of the Republic of Indonesia and that the certificate of land rights is growing evidence of an ownership or control of land ${ }^{5}$

Land Registry is a series of activities carried out by the Government continuously, continuous and regular, covering the collection, processing, accounting, and presentation as well as the maintenance of physical data and juridical, in the form of maps and lists, on plots and apartment units, including providing proof of its right to the land areas of existing rights, and ownership of the apartment units as well as certain rights which encumber

Land Registry Systematic Complete is a land registration activities for the first time carried out simultaneously for all the objects of registration of land in the entire territory of the Republic of Indonesia in the territory of the village / village or other names that level with it, involves the collection and determination of the truth of physical data and juridical data regarding one or several objects of registration of land for registration purposes. In a complete systematic land registration activities, hereinafter referred to PTSL implemented by the Adjudication Committee for Complete Systematic Land Registration.

Land registration systematically is one of the efforts made for promoting the certification of the land as well as to involve the active participation of the community, especially the land-rights holders to cooperate with the government of the convening of land registration, then the parties concerned can easily know the status or legal position rather than a particular land that it faces, the location, area and boundaries, who have and load what is on it. ${ }^{6}$

Grobogan has approximately 790,000 including 570,000 parcels of land that have not been certified. So that Grobogan District Land Office in 2019 targeted PTSL program doubled from 2018. In 2018 of approximately 55150 land parcels included in the program PTSL and realized a number of 33,000 parcels of land. In 2019, the number of which is included in this program as many as 70,000 field. There are 16 districts be included in the program PTSL in Grobogan.

Land Deed Official hereinafter called PPAT is a public official who is authorized to make the deeds authentic about a certain legal actions regarding land rights or ownership of the apartment units ${ }^{7}$

Another definition of PPAT, which is mentioned as a public official who is authorized to make the deed of transfer of land rights, land rights imposition deed, and the deed giving the authority to the security rights according to the legislation which berlaku.Boedi Harsono states that a public official is a person who was appointed by

\footnotetext{
${ }^{4}$ Boedi Harsono, 2008, Hukum Agraria Indonesia: Himpunan Peraturan-Peraturan Hukum Tanah, Djambatan, Jakarta, p. 14

${ }^{5}$ F.X. Sumarja, 2012, Problematika Kepemilikan Tanah Bagi Orang Asing, Indepth Publising, Bandar Lampung, p. 9-10

${ }^{6}$ Effendi Perangin, 1991, Hukum Agraria Indonesia, CV. Rajawali, Jakarta, p. 95

${ }^{7}$ Article 1 point 1 of Government Regulation No. 24 of 2016 on the amendment to Government Regulation No. 37 of 1998 on the Regulation of Land Deed Official Position.
} 
Volume 6 Issue 4, December 2019

Nationally Accredited Journal,

Decree No. B/4130/E5/E5.2.1/2019

the government with the task and authority providing services to the public in a particular field. ${ }^{8}$

PPAT Deed is an authentic deed, among others Boedi Harsono stating that PPAT deed under the Act as stated in Article 19 paragraph (1) BAL. In relation to that asserted in the General Explanation of item 7 of Act No. 4 of 1996 on Mortgage of Land Along Objects Relating to Land (UUHT), that the deeds made by PPAT an authentic deed. With PPAT in UUHT declared as public officials doubting ending regarding naming, status of law, the duties and authority of the PPAT. ${ }^{9}$

Based on the backland mentioned above, the authors are interested in doing further research to be formulated in the form of research under the title: "The Implementation of Complete Systematic Land Registration (PTSL) Which the Transfer of Rights of His Land Not Using PPAT Deed"

\section{Research methods}

The method approach used in this study using sociological juridical approach namely a study conducted in depth against the reality. A reality that exist within the community and surrounding environment for the purpose of finding facts there and then will discuss the problems that exist. This study used analytic descriptive outlines of the realities that exist and implemented in a systematic, thorough, and factual, using legal theories that did not exist and the legislation relating to the object under study.

\section{Results and Discussion}

\subsection{The Implementation of Complete Systematic Land Registration}

According to Florian SP Sangsun, systematic land registration is land registration activities for the first time carried out simultaneously covering all the objects of registration of land not yet in the list in a region or part of the territory of a village / village. Systematic land registration is based on a work plan and implemented in the areas specified by the Minister. Systematic land registration conducted on the initiative of the Government, then the activity is based on a work plan established by the Minister. ${ }^{10}$

Grobogan is one area that participated in the systematic land registration activity is complete, since many people in Grobogan who have not registered their land rights. Systematic Land Registration Event Complete an agenda that has been set by the Land Office Grobogan, these activities serve to help people register their land rights. Following the phase-conversion stages are carried out through activities Accelerating the Implementation of Complete Systematic Land Registration

The stages that must be done in the implementation of a complete systematic registration of land namely:

\footnotetext{
${ }^{8}$ Salim HS, 2016, Teknik Pembuatan Akta Tanah Pejabat Pembuat Akta Tanah, Rajawali Pers, Jakarta, p. 87.

${ }^{9}$ Boedi Harsono, 2008, Hukum Agraria Indonesia, Sejarah Pembentukan Undang-Undang Pokok Agraria, Isi dan Pelaksanaannya, Djambatan, Jakarta, p. 432.

${ }^{10}$ Florianus SP Sangsun, Tata cara mengurus sertifikat tanah, Visi Media,Jakarta,2007, p 23.
} 


\subsubsection{Determination location}

The stipulation made by the Chief of the Land Office was made on location PTSL activities in the areas they can be in one of the districts, villages, and villages. If there are particular circumstances, the Head of the Land Office can make changes PTSL predefined location, as well as made in the form of a decision by the Land Office on PTSL location changes.

\subsubsection{Counseling}

Counseling is a very important thing to do before A committee is formed, then the committee must immediately do counseling. Prior to the extension, Grobogan District Land Office to coordinate early with the Head of the Village, the location of PTSL. The aim of the initial coordination was to inform the citizens that will in land registration implementation through PTSL in the village.

The adjudication committee PTSL there is a committee that comes from the land office employees which include physical field who understand the affairs of the land infrastructure, juridical field who understand the legal relationships of land affairs, secretary, and members of this committee are also derived from the land office, as required. That the adjudication committee PTSL physically assisted by officers, judicial officers and administrative officers. If necessary, the Head of BPN Regional Office may designate Apparatus of the regional office of the State Civil BPN land office as an officer or physical, judicial officer or clerk to assist in the implementation of activities PTSL another land office in one province.

Head of the Land Office along PTSL adjudication committee, the clerk Physical and juridical officers to educate more people, either already or not yet have a certificate, as well as to regional governments, relevant agencies, law enforcement and / or community leaders. In terms of physical data collection and data collection juridical, Head of the Land Office must ensure conformity of the data generated from activities PTSL with electronic data in the application of the CTF. For the purposes of proving the right, PTSL adjudication committee conducting research juridical data.

\subsubsection{Data Collection}

After counseling to several districts and villages, the next stage of data collection. Officers will conduct Documenting the public about the history of the land, such as who the previous owner of the land, for example on the basis of ownership grants, Purchase and from legacy and proof of deposit tax and income tax BPHTB

The Village has a duty to get anyone who is entitled to participate in this PTSL, the village head PTSL program are entitled to request and collect data from people faithful who will join the program, and then handed over to the authorities to accept it. Among them are:

- Photocopy of ID card and KSK applicant

- Stick Sign D original or a copy of the Letter C / C Quotes Village

- Attach original proof of ownership / acquisition of land, among others, the Deed of Sale and Purchase / Grant / Swap / Certificate of Inheritance / Seal / Receipt / Statement Under Hands.

- Attach a history of land made by the Village Head

- Attach the required certificate

- Attach SPPT / UN

- Attach the petition as follows:

- Application for the issuance of certificate 
Volume 6 Issue 4, December 2019

Nationally Accredited Journal,

Decree No. B/4130/E5/E5.2.1/2019

- Affidavit physical control plot

- Affidavit of land dispute

- A letter stating the land is not under warranty

- Shows the location and boundaries of land requested

- Installing mark land plane) Submit proof of deposit BPHTB and Income

\subsubsection{Measurement}

After passing through several administrative stages and passed the next steps that the officer will take measurements of the soil, covering the length measurement, the shape of the field, the width of land owned and land parcel boundary. In other side the land measurements also require the consent of the owner of the adjoining land

\subsubsection{A committee hearings}

Head of the Regional Office of the National Land Agency Provincial conduct an inventory of the number of employees who can be deployed as a committee and task force juridical, The Committee on Land Registry Systematic Complete called Committee of Adjudication Acceleration amounted to 4 employees of the National Land Agency plus one of the urban / rural, and its membership can be added as needs. For data collection Juridical Committee Adjudication Acceleration assisted by the Task Force Juridical which comprises at least 1 (one) of the Civil Service National Land Agency and 1 (one) local residents as needed, the Committee of Adjudication Acceleration can be accompanied / supported by data collectors judicial or judicial task force in accordance with the volume / target,

Juridical data collection and analysis completed in one fiscal year by taking into account periods of activity phase comparison between the capacity of the Adjudication Committee for the Acceleration and Judicial Task Force with the target volume based on the specified field (according to the guidelines form)

Acceleration adjudication committee has the task:

- Analyze / juridical process data collected on parcels of land that may or may not be certified.

- Categorizing each juridical data into kluster 1,2,3, and

- To examine the land along with other members of the Adjudication Committee (Annex 6 technical guidelines: minutes of land inspection)

- Implement announcement juridical data as shown in Annex III Regulation of the Minister of Agrarian and Spatial Planning / Head of National Land Agency No. 35 of 2016 and validate the results announcement juridical and physical data along with members of other Adjudication Committee (Annex 6 technical guidelines: Minutes of the Ratification Results Announcement)

- Preparing Decree and the Decree Determining Rights Assertions / Recognition of Rights (Annex 8a and 8b technical guidelines:: Determination Rights Decree and Decree Assertions / Recognition of Rights)

- Setting up a bookkeeping process rights and the issuance of certificates

- In the case of adjudication committee members deemed necessary acceleration of the elements can be added as needed Land Office

\subsubsection{Announcement and Endorsement}


After passing through a committee hearing, the committee will announce the results then officers will conduct attestation approximately 14 days after the announcement was pasted in the village or village office or the local land office. If within 14 days there is no objection, the land which is registered stated no problems and is not a conflict land, so can continue to be issued a certificate. The announcement lists the name, area, location of the land, plot maps, and other information.

\subsection{7. issuance of Certificates}

The last stage is the issuance of certificates conducted by the Ministry of Agrarian Spatial / National Land Agency being authentic proof someone on his land ownership shared directly with landowners

\subsection{Constraints Happens In Implementation of Complete Systematic Land Registration}

\subsubsection{Lack of public awareness of the importance of having evidence of land ownership} in the form of Certificate of Property Rights.

Position Certificate As Evidence Rights In accordance with the provisions of Article 19 BAL certificate is a certificate of proof applicable right as a means of proof is strong, then it is repeated again the affirmation in article 39, but with a clause that this is true for not yet been demonstrated, contrary which by some parties considered to weaken the position of a certificate as evidence is strong. But 5 years to file a lawsuit then it is even more assured certainty.

In addition to understanding the certificate provided by the law is authentic, there is also the sense certificate given by scholars. One is K. Wantjik Saleh stating that the certificate is a copy of the book and the letter of the measuring soil after bound together with a paper cover determined by the Minister ${ }^{11}$

Why certificates as a means of evidence, not as an absolute proof? This relates to the publication system adopted by the land law of Indonesia both Government Regulation No. 10 of 1961 and Government Regulation No. 24 of 1997 which is a system of negative publicity that contains positive elements because it will generate letters proof of rights (certificates) which acts as a tool evidentiary. So there is no system of positive publicity, because according to the system of positive publicity is what is listed in the land registry and letters of proof of the rights issued a proofing tool that absolute third party (good will) which acts on the basis of such evidence is not received protection, even if later it turns out that the particulars contained therein are not true ${ }^{12}$

\subsubsection{The village committee lack of understanding about what it must be prepared in the implementation of this PTSL}

Lack of understanding of the Village Committee understandings on this case that resulted in the slow process of pelasaan PTSL Grobogan. At this very activity PTSLLocal Government expected an active role in bridging between the land office as the main implementer PTSL program and the village government as the ruler of the territory.

\footnotetext{
${ }^{11}$ K. Wantjik Saleh, 1977, Hak Anda Atas Tanah, Penerbit Ghalia Indonesia, Jakarta, p.64.

${ }^{12}$ Syamsul Bahri, 1981, Hukum Agraria Indonesia Dulu dan Kini, Publisher of Faculty of Law and Society Knowledge, University of Andalas, Padang, p. 22.
} 
Volume 6 Issue 4, December 2019

Nationally Accredited Journal,

Decree No. B/4130/E5/E5.2.1/2019

According to Article 371 of Act No. 23 of 2014 on Regional Government, the Village Government in exercising its authority, then as the village administration together with the Village Consultative Body may establish Village Regulations as a normative basis in the administration of village affairs. Village Regulations in addition to functioning as a normative basis in the administration of the village administration, also serves to accommodate the aspirations and conditions of the community.

\subsubsection{History land is hard to come}

certificate of the land is the first process or the right base to get a certificate of land rights. Existence Certificate of Land (SKT) in Indonesia is recognized in the Basic Agrarian Law, Government Regulation No. 10 of 1961 About the Land Registry and Government Regulation No. 24 of 1997 on Land Registration.

SKT is written evidence under the hand of the power of proof is not as strong as authentic deeds, but because SKT is a securities categorized as the right base or juridical data on land used as a condition of compliance with requirements for the right to land as stipulated in the legislation, then SKT is a very important document in the process of issuing land rights certificates.

\subsection{Solutions In the implementation of Complete Systematic Land Registration}

- BPN to Grobogan should improve employee performance in program implementation PTSL in Grobogan.

- To Village Government should be more pro-active and provide support for the implementation of the program by taking part PTSL assist officers BPN

- Responsible PTSL urge all members on duty to be more careful in selecting files to be the requirements of the participants. It should also coordinate with each other so that errors in the file selection process can be minimized.

\section{Closing}

\subsection{Conclusion}

Based on this research can be concluded that the implementation of land registration systematically complete, there are several barriers among others are plots of land still in dispute, plots the subject is still not clear, less pro-active society and as other but officials PTSL seeks to overcome barriers with effective solutions in order to program this PTSL on going well and smoothly in the interests of the general public

\subsection{Suggestion}

- Grobogan district land office must be meticulous in the process of implementing this PTSL in order to minimize the errors that will occur

- And PTSL officers committee should scrutinize to the terms or file owner of the land, lay of the land, land area and ensure the real owners of the land in order to avoid mistakes

\section{References}


[1] Boedi Harsono, 2008, Hukum Agraria Indonesia: Himpunan Peraturan-Peraturan Hukum Tanah, Djambatan, Jakarta

[2] ----------------, 2008, Hukum Agraria Indonesia, Sejarah Pembentukan UndangUndang Pokok Agraria, Isi dan Pelaksanaannya, Djambatan, Jakarta

[3] Effendi Perangin, 1991, Hukum Agraria Indonesia, CV. Rajawali, Jakarta

[4] Florianus SP Sangsun, Tata cara mengurus sertifikat tanah, Visi Media,Jakarta,2007

[5] F.X. Sumarja, 2012, Problematika Kepemilikan Tanah Bagi Orang Asing, Indepth Publising, Bandar Lampung

[6] K. Wantjik Saleh, 1977, Hak Anda Atas Tanah, Penerbit Ghalia Indonesia, Jakarta

[7] Salim HS, 2016, Teknik Pembuatan Akta Tanah Pejabat Pembuat Akta Tanah, Rajawali Pers, Jakarta

[8] Syamsul Bahri, 1981, Hukum Agraria Indonesia Dulu dan Kini, publisher of Faculty of Law and Society Knowledge, University of Andalas, Padang 